\title{
Green dream: examining the barriers to an innovative stormwater and public open space structure plan on Perth's suburban fringe
}

Julian Alexander Bolleter

To cite this article: Julian Alexander Bolleter (2020): Green dream: examining the barriers to an innovative stormwater and public open space structure plan on Perth's suburban fringe, Australian Planner, DOI: 10.1080/07293682.2020.1739090

To link to this article: https://doi.org/10.1080/07293682.2020.1739090 


\title{
Green dream: examining the barriers to an innovative stormwater and public open space structure plan on Perth's suburban fringe
}

\author{
Julian Alexander Bolleter \\ Australian Urban Design Research Centre, University of Western Australia, Perth, Australia
}

\begin{abstract}
The Wungong Landscape Structure Plan (LSP), currently under construction on the fringes of Perth, embodies a number of innovations with respect to Public Open Space (POS) provision. These include the proposition of a holistic, interconnected POS system that transcends individual property ownership, an integrated POS and stormwater management system, and the use of a POS system as the primary guidelines for development. There has been significant resistance to these innovations from within the urban design and planning disciplines, the land development industry, and from regulatory bodies. This paper examines these various barriers to implementation to inform future suburban projects that attempt related innovations.
\end{abstract}

ARTICLE HISTORY

Received 1 September 2017

Accepted 3 March 2020

\section{KEYWORDS}

Water sensitive urban design; Wungong; greenfield

development; geomorphic wetlands; New Urbanism

\section{Introduction}

The Australian Bureau of Statistics (ABS) project that Perth's population will increase from 1.9 to 4.9 million by 2066 (2017). Given Perth generally struggles to achieve its $47 \%$ target for infill development (Bolleter 2016); this population growth is likely to result in further waves of suburban expansion. On Perth's southeast and northeast development front, land developers are delivering new suburban developments on low lying, geomorphic (groundwater-dependent) wetlands (Figure 1) (Singh et al. 2012, 6).

\section{The Wungong project}

The 'Wungong' project is emblematic of this situation. The project encompasses an area of over 1400 hectares of low-lying land on Perth's south-eastern development front and planners project that upon completion it will yield 16,000 compact homes, with a total population of 40,000 people (Wood-Gush 2008, 8). An innovative Public Open Space (POS) system, integrated with a comprehensive stormwater management system, structures the overall suburban form (Weller 2008 , 258) which acts to accommodate the high groundwater situation.

The origins of the Wungong Landscape Structure Plan (LSP), in part, derive from a 2004 provocation by the then client, The Armadale Redevelopment Authority (ARA), ${ }^{1}$ to the design team. The University of Western Australia landscape architecture program, for a concept LSP 'as if the landscape really mattered' (Brett WoodGush in Weller 2009, 239). The LSP was produced by a team of over 60 consultants - representing 38 different organisations - who spent three years (2004-2007) testing its configuration and refining its ideas (Weller 2008, 257). It remains the overarching plan used by the Metropolitan Redevelopment Authority (MRA) for 'guiding' the development of the Wungong project area (project director).

\section{Controversy about the Wungong project}

In 2007 the Wungong LSP received the Planning Institute of Australia's 'President's Award for Planning Excellence' and the 'Planning Excellence Award' under the category of 'Environmental Planning or Conservation' (Ellis 2010, 3) and subsequently the LSP was published in Australian Planner in 2008 (Wood-Gush). At the time, the project was also the only suburban development in Australia to be offered funding under the then Federal Government's 'Water Smart Australia program' (Wood-Gush 2008, 8). Perhaps justifiably given the awards received, Brett Wood-Gush from the LSP design team, described the project as having a depth of innovation that is 'truly astounding' and an overall 'model of development that is exceptional' (Wood-Gush 2008, 8). However, subsequently in a non-mandatory 2010 peer-review the project has been regarded as 'impractical' (Jones et al. 2010, 2), 'concerning' (Jones et al. 2010, 2), a 'deeply flawed vision' (Burrell 2010, 1) and in another forum, a 'disaster' by a past Western Australian President of the Urban Development Institute of Australia (UDIA). Certainly, the project has elicited strong reactions within the Western Australian planning and land development communities. In this paper, we seek to understand the resistance to the Wungong LSP, so to 


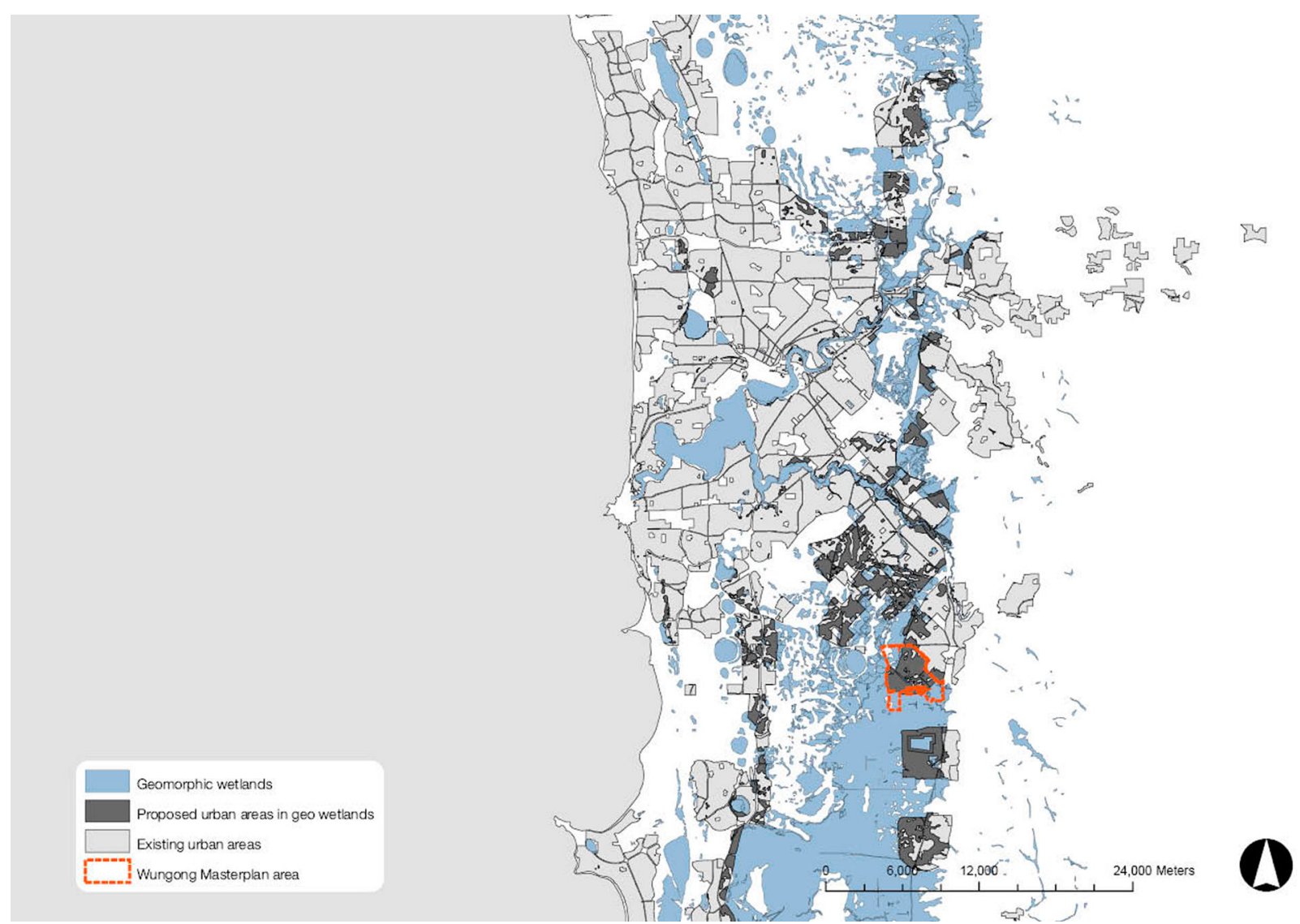

Figure 1. Many new suburbs, on the south-east and north-east development front are in many cases being developed on land with is geomorphic (groundwater dependent) wetlands.

develop mitigation strategies that planners can utilise in future urban projects attempting similar innovations.

\section{The Wungong LSP principles}

The Wungong LSP embodies Water Sensitive Urban Design (WSUD) in that it attempts to integrate urban development 'with the management, protection and conservation of the urban water cycle', in turn ensuring that urban water management is 'sensitive to natural hydrological and ecological processes' (Wong 2006, 214). The Wungong LSP contains two principle innovations that we set out in the following section.

\section{An integrated and holistic POS and stormwater system}

The 'environment' of the Wungong project area consists of relatively flat, degraded agricultural land with high clay content soils. The combination of clay soils, water entering the site from the nearby escarpment, and poor drainage means the land experiences short periods of seasonal surface inundation (Brett WoodGush in Weller 2009, 243) (Figure 2). In response to this challenging hydrological situation, the Wungong LSP proposes a 'POS system integrated with a comprehensive stormwater management system as a legible infrastructural component of the project' system (Weller 2008, 258) (Figures 3 and 4). The planners intend the stormwater management system will receive and cleanse stormwater from the future suburban subdivisions before it enters the nearby Wungong River (Sack et al. 2004, 3).

At the same time, the POS system which forms a holistic system across the whole development area, encourages active modes of transport, conveys wildlife, protects and connects Aboriginal heritage sites (WoodGush 2008, 10), and provides the 'otherwise raw suburban development with a distinctive and binding character on a scale commensurate with the development' (Weller 2009, 251). As then Director of the Armadale Redevelopment Authority (ARA) explains of the linear network, 'we visualised flying over Perth at 30,000 feet and being able to see Wungong and seeing the straight lines of the linear POS - like Louis the Fourteenth coming to Perth ...' (project director). The linear network POS itself consists of Living Streams, Park Avenues and Community Parks - which adjoin the Living Streams (Wood-Gush 2008, 10).

The Living Streams are essentially reconfigured open drains that are a legacy of the site's agricultural past and poor drainage (Figure 5). Given that such drains are typically weed-infested and polluted (Pen and Majer 1994, 194) the Wungong LSP proposes that the route of these drains is substantially altered 


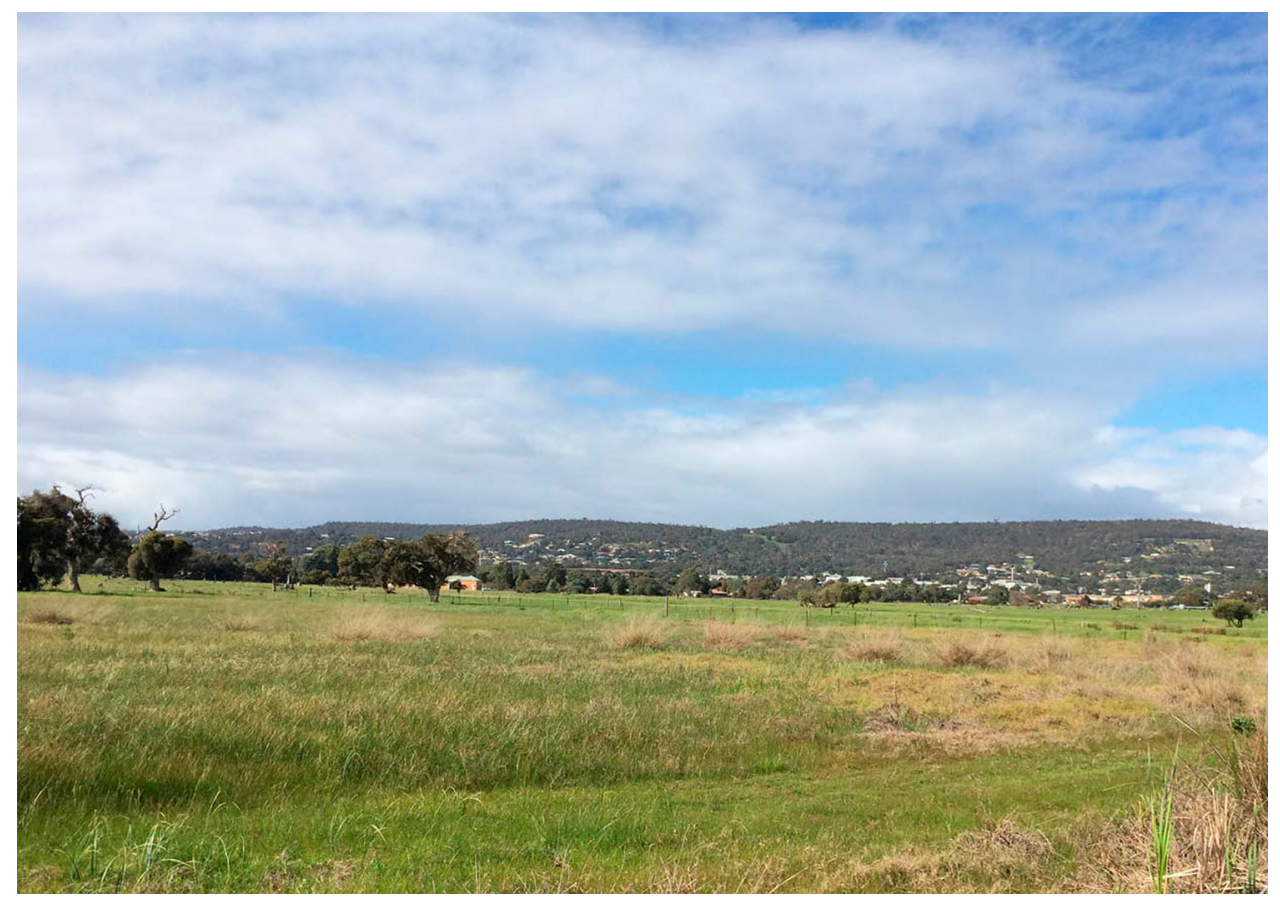

Figure 2. The 'environment' of the Wungong project area consists of relatively flat, degraded agricultural land with high clay content soils. The combination of clay soils, water entering the site from the nearby Darling escarpment, and poor drainage means the land experiences short periods of seasonal surface inundation.

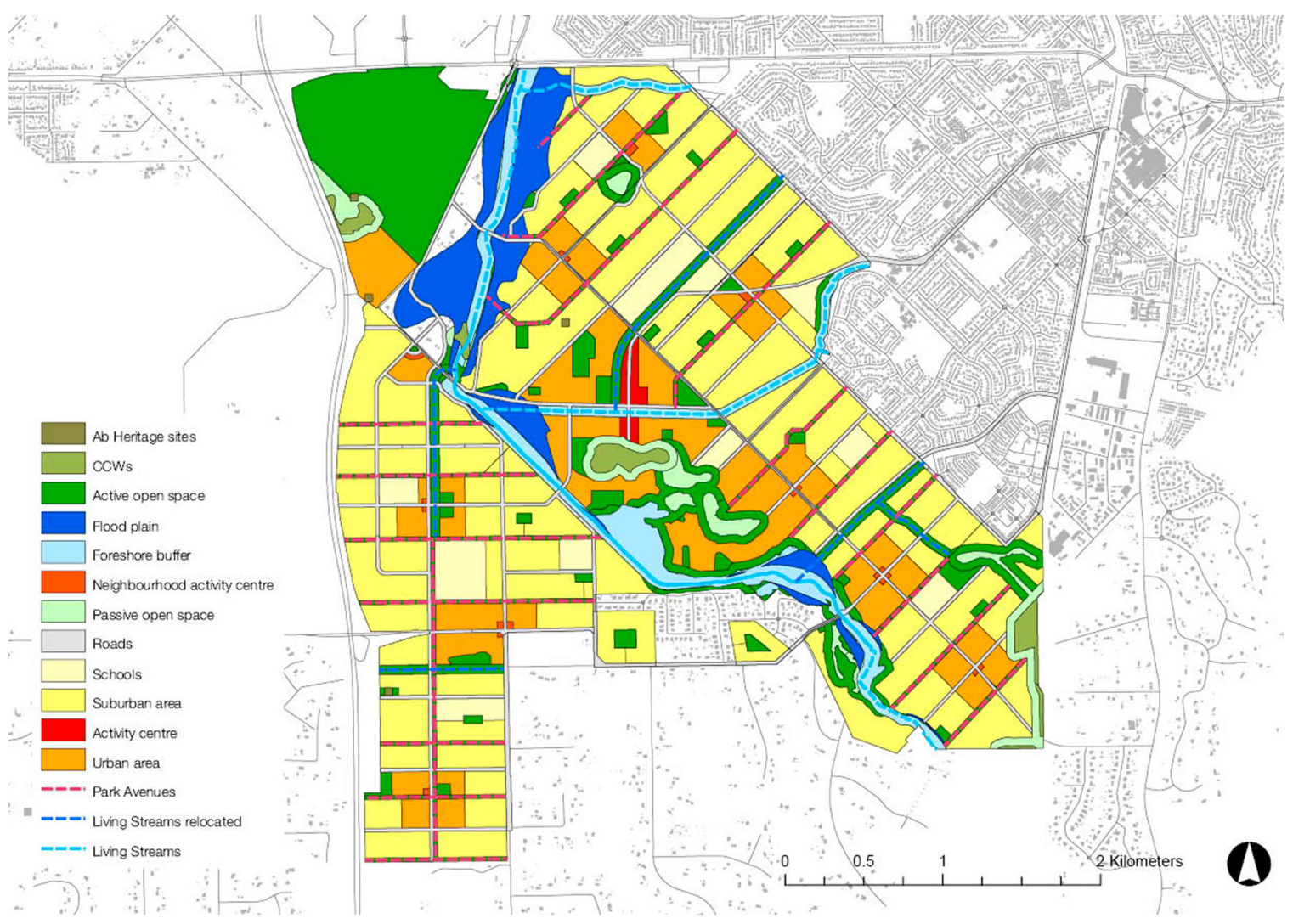

Figure 3. The Wungong Landscape Structure Plan (LSP).

to make them conform to a fairly rigid orthogonal structure, and deliver recreational and ecological functions.

Complementing the Living Streams in the LSP is a sequence of linear swales, referred to as Park Avenues, framed by avenues of (typically) Eucalyptus trees
(Figure 6). The planners intend the Park Avenues will function as a meeting place, encourage walking (Brett Wood-Gush in Weller 2009, 243), offer vistas of the Darling Escarpment to the east, mitigate the harsh easterly winds, funnel cooling sea breezes, function as habitat corridors, and retain the 


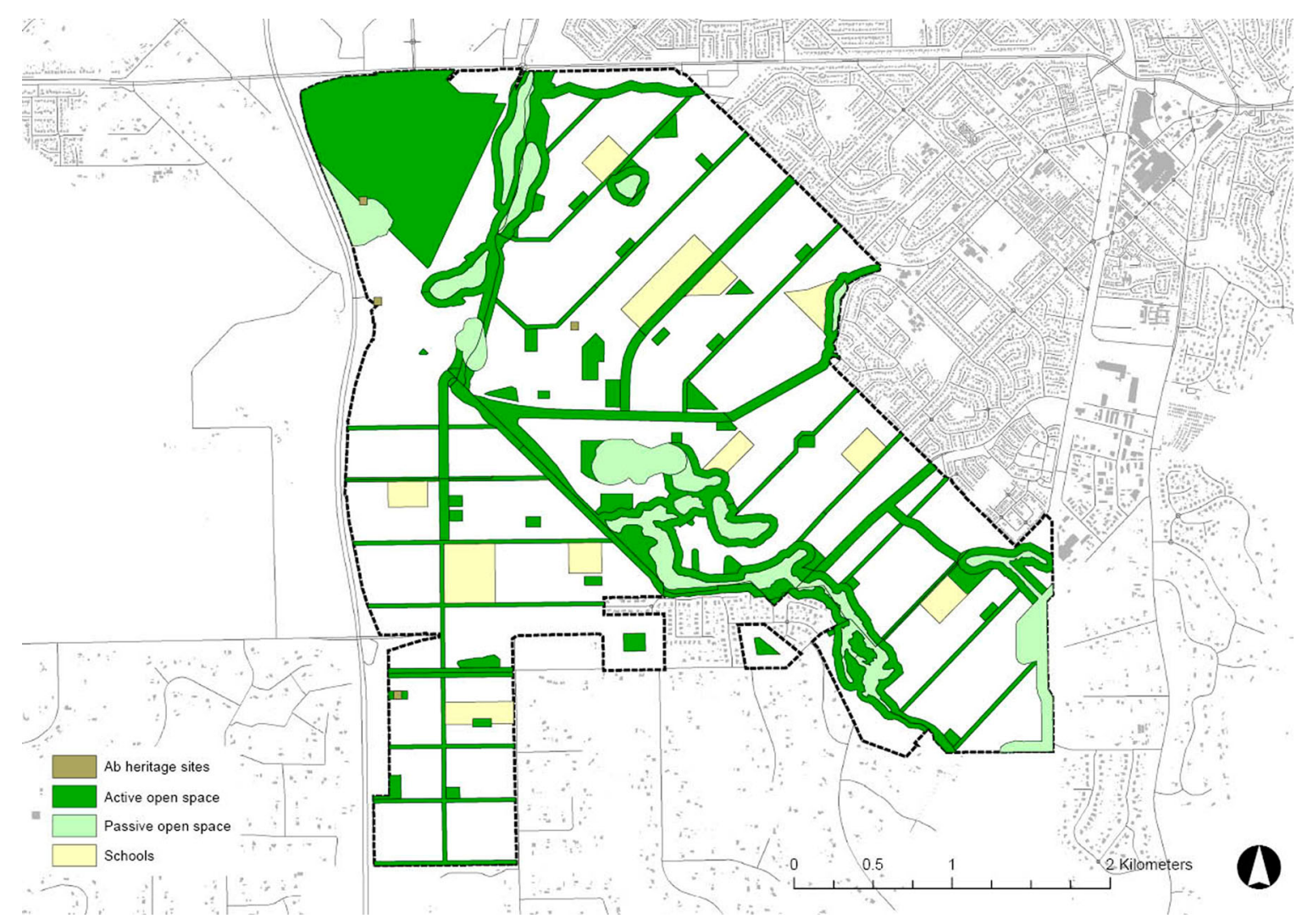

Figure 4. The Wungong LSP proposes a POS matrix integrated with a comprehensive storm water management system.

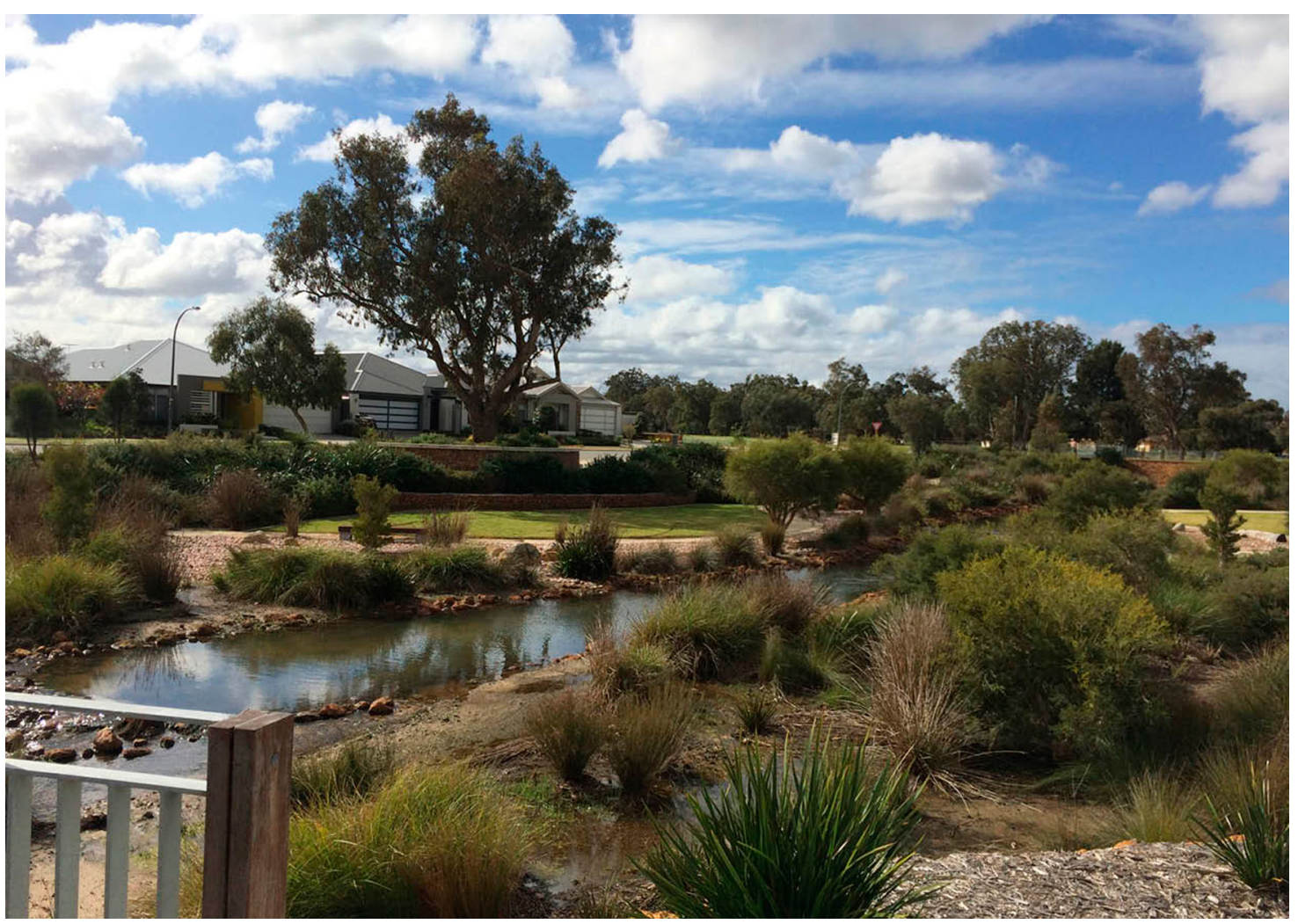

Figure 5. The Living Streams are essentially retrofitted open drains which are a legacy of the site's agricultural past and poor drainage. The Wungong LSP proposes that the route of these drains is substantially altered to make them conform to a generally orthogonal structure, and to become multifunctional with respect to delivering recreational and ecological functions. 


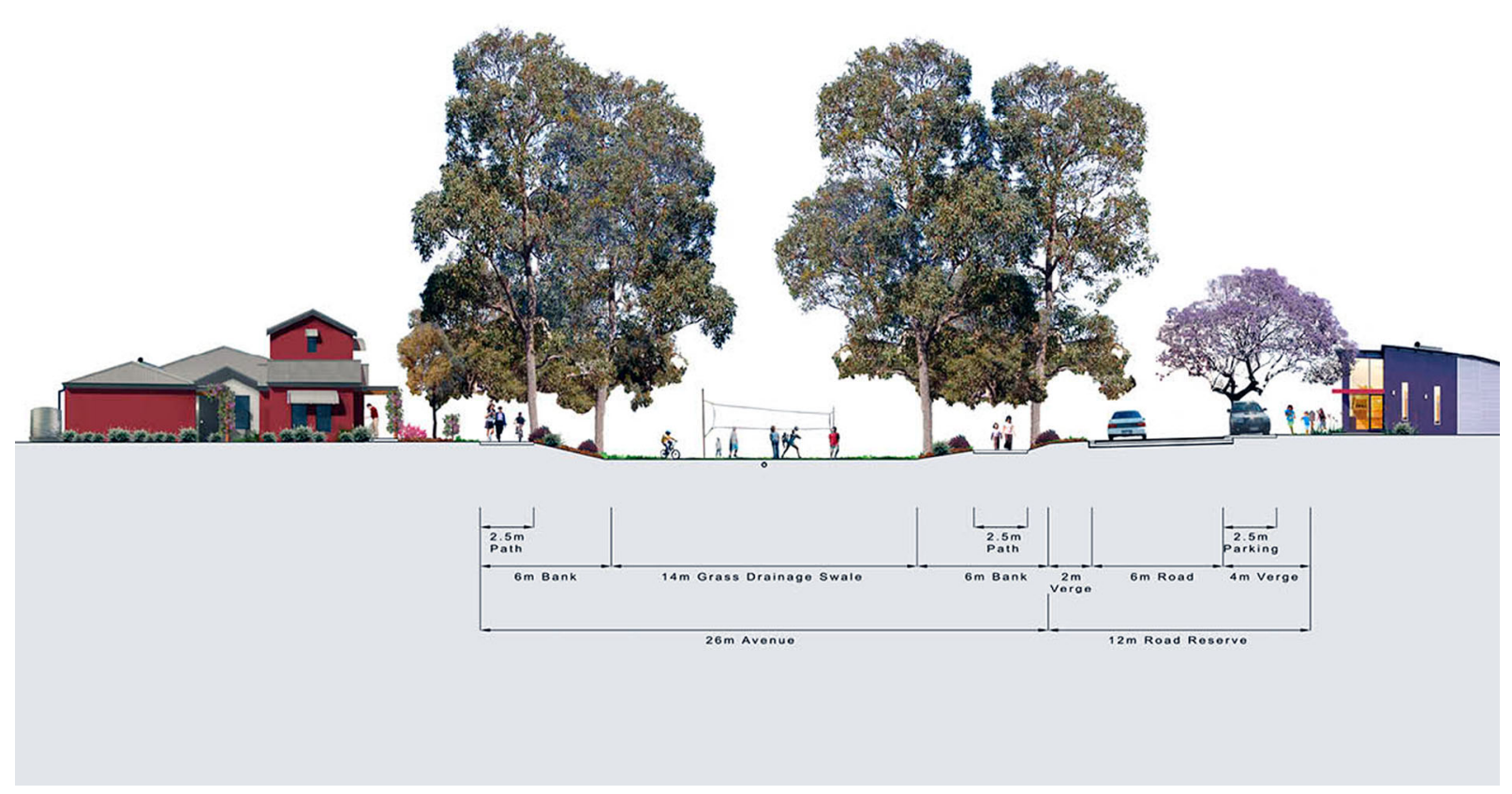

Figure 6. Complementing the Living Streams in the LSP is a sequence of linear swales, referred to as Park Avenues, leading to the Wungong River framed by avenues of (typically) Eucalyptus. The Park Avenues are intended to function as a meeting place for nearby residents, allow for extensive pedestrian access throughout the development (Image courtesy of Richard Weller).

natural character of the rural landscape (Sack et al. 2004, 4).

Along each Park Avenue is located a 0.6 ha square open space (on average) at the heart of each neighbourhood. In addition to stormwater retention, these spaces also function to facilitate active play space areas and help cater for the recreational needs of the surrounding neighbourhood (Metropolitan Redevelopment Authority $2012 b, 3)$.

\section{A POS system as the primary guidelines for development}

More than merely 'ornamental' POS, that characterises many suburban developments in Perth, the Wungong LSP integrated POS and stormwater management system functions as the primary guidelines for subsequent development (Weller 2008, 258). In this sense, it acts as a structuring device that informs the location of Activity Centres and denser urban areas, primary and high schools as well as informing the geometry of the road network which runs both parallel and perpendicular to the linear POS network (Weller 2009, 251). It is through this structuring role of linear POS that the Wungong project arguably provides an example of the broadening of landscape architecture's field of influence into infrastructural and city planning based issues (Weller 2006b, 67).

In conventional Perth, Business As Usual (BAU) suburban development, developers raze site endemic vegetation and topography to create a flat site for the deployment of standardised project homes. In relation to the effective tabula rasa that results, developers often employ landscape architecture to reconnect the transformed site to 'place'. As Richard Weller explains:

In deference to a 'sense of place', the landscape that the new suburb almost inevitably erases is returned to the new development as thematic veneer, a symbolic pastiche or hapless remnant of its former self. (Weller 2008, 247)

In part as a response to this situation the Wungong LSP, seeks the creation of a new suburban model 'where environment and urban development exists in an interwoven system' (Wood-Gush 2008, 11), and in which the landscape itself could genuinely inform the character and structure of the suburban development (Sack et al. 2004, 1).

\section{Method}

\section{Research question}

In order to address the impediments the planning team encountered in delivering the innovative Wungong LSP, and so that future planners learn lessons from this experience, we have structured this research paper with reference to the following research question:

What have been the dominant barriers, from planning the discipline, developers and regulators to the implementation of the proposed Public Open Space innovations of the Wungong LSP?

Subsequently we pose the question:

What mitigating strategies could future planners adopt to mitigate the barriers to such Public Open Space innovations? 
To explore these research questions we have adopted a 'case study' analysis methodology. A case study analysis is an empirical inquiry that investigates a project within its real-life context (Groat and Wang 2002, 346). In this respect, the paper investigates the practicality of implementing the following key principles proposed in the Wungong LSP:

- Create a holistic system of POS that transcends individual property ownership (Weller 2008, 258).

- Create an integrated POS system and stormwater management system (Weller 2008, 258).

- Assert the POS system as the primary guidelines for subsequent development (Weller 2008, 258).

We have based our case study analysis on a comprehensive review of the literature concerning the Wungong LSP (Jones et al. 2010; Burrell 2010; Metropolitan Redevelopment Authority 2012a, 2012b; Ellis 2010; Armadale Redevelopment Authority, n.d.) and eight face-to-face, semi-structured interviews (using pre-determined questions and asking additional questions based on the responses). We asked interviewees about their opinions on the obstacles to the principles, and their recommendations for strategies to mitigate these barriers. A certain amount of 'spontaneity and uncertainty characterises this method' (Carrington and Marshall 2008, 120) - nonetheless we covered all questions with interviewees.

\section{Sampling}

We initially employed purposive sampling (Kelley et al. $2003,264)$ to select our interviewees. Interviewees we selected included civil engineers, urban designers, landscape architects, and hydrologists who were involved in the planning and delivery of integrated stormwater/ POS projects at Wungong. We also interviewed state government regulators who oversaw the design and operation of stormwater systems integrated with POS, and redevelopment authority directors and project directors who have been, at various points, responsible for the delivery of the Wungong LSP. We recruited respondents initially through the representatives of government departments on our research centre's board. Subsequently we used a snowballing sampling method i.e., as we surveyed one individual we invited them recommend others for us to survey.

\section{Review of interview transcripts}

The interviews lasted between 30 and $60 \mathrm{~min}$ and we recorded and transcribed them verbatim after completion, yielding hundreds of pages of text. We then subjected the transcripts to manual textual and interpretative analysis to identify key themes. Subsequently, we removed all identifying information regarding participants - other than their professional roles with our aim to extract the key themes from the responses.

\section{Results}

We have set out the results of the interview and literature review process in the following tables. Figure 7 identifies the barriers to the innovative principles proposed in the Wungong LSP from the perspective of Perth's urban design and planning disciplines, the land development industry, and regulatory bodies. Figure 8 sets out several mitigating strategies that planners could adopt to mitigate the aforementioned barriers in future projects attempting similar innovations in WSUD POS systems.

\section{Discussion}

The resistance to the Wungong LSP is, to varying degrees ideological, technical, economic and institutional - a formidable combination of factors for any one project to overcome. The resistance the LSP, received particularly in the 2008-2010 period, also reflected a number of macro political and economic factors that are of importance. In part, the resistance to the project reflected a change of state government in 2008 and the loss of a planning minister, Alannah McTiernan, who had been supportive of the Wungong LSP (project director). It is understood that upon the change of state government the developers involved in delivering the Wungong LSP, saw an opportunity to 'vent their spleen' (project director), and complained to John Day the then new planning minister. As an exproject director explains 'if the developers had complained like that to Alannah McTiernan she would have said, "there's the door" however unfortunately John Day didn't have a history of the area ...' and he had the 'developers in his ear' (project director). ${ }^{2}$ Perhaps because of this the new planning minister 'set up an enquiry into Wungong, and many of the criticisms of the project from within the planning discipline formed part of this enquiry. In part, as a result an MRA based implementation team replaced the large LSP team - without almost any 'continuity' between these teams (project director).

Moreover, developer led resistance to the Wungong LSP also reflected that by 2010 the economic context had tightened up, in comparison to 2004-2007 when the LSP was conceived, and as such developers were increasingly less inclined to take risks by deviating from BAU development models.

\section{Resistance from within the planning disciplines}

Arguably, agendas ideological or otherwise drove some of the negative assessments of the Wungong LSP from 


\begin{tabular}{|c|c|c|c|}
\hline Wungong LSP innovations & $\begin{array}{l}\text { Resistance from within planning and } \\
\text { urban design disciplines, based on: }\end{array}$ & Resistance from developers, based on: & $\begin{array}{l}\text { Resistance from regulatory bodies, } \\
\text { based on: }\end{array}$ \\
\hline Holistic POS system & $\begin{array}{l}\text { - Perception of inequitable distribution of } \\
\text { open space } \\
\text { - Perception of over-provision of narrow } \\
\text { linear open spaces }\end{array}$ & $\begin{array}{l}\text { - Perception that the Developer } \\
\text { Contribution Scheme (DCS) set up to } \\
\text { fund the implementation of a holistic, } \\
\text { interconnected POS system was unfair } \\
\text { because some development sites were } \\
\text { a long way from proposed POS. }\end{array}$ & $\begin{array}{l}\text { - Perception by local government that the } \\
\text { narrowness of the Living Streams and } \\
\text { Park Avenues are not functional and } \\
\text { reflect a deprivation of recreational } \\
\text { opportunity - particularly from the } \\
\text { perspective of active recreation. }\end{array}$ \\
\hline Integrated POS and stormwater system & $\begin{array}{l}\text { - Perception of inadequate provision of } \\
\text { appropriately useable public open } \\
\text { space }\end{array}$ & $\begin{array}{l}\text { - Perception that the LSP's holistic POS } \\
\text { stormwater system poses coordination } \\
\text { issues in relation to how drainage } \\
\text { networks are coordinated from one site } \\
\text { to another. }\end{array}$ & $\begin{array}{l}\text { - Perception by Living Stream planning } \\
\text { teams that overlapping recreational and } \\
\text { hydrological functions of Living Stream } \\
\text { and Park Avenues is causing delays in } \\
\text { design approvals because of the large } \\
\text { number of regulatory bodies who are } \\
\text { required to approve designs. } \\
\text { - Perception by Living Stream planning } \\
\text { teams that the drainage related } \\
\text { regulatory bodies (in this case Water } \\
\text { Corporation) is as an impediment to the } \\
\text { delivery of multifunctional, integrated } \\
\text { stormwater and POS matrices because } \\
\text { their sole role is to consider drainage } \\
\text { not multifunctional open space } \\
\text { Confusion about the responsibilities for } \\
\text { the ongoing maintenance of } \\
\text { multifunctional stormwater and POS } \\
\text { matrices. }\end{array}$ \\
\hline $\begin{array}{l}\text { POS system as the primary guidelines for } \\
\text { development }\end{array}$ & $\begin{array}{l}\text { - Perception that the LSP lacked a mixed } \\
\text { use town centre and that the } \\
\text { distribution of urban centres did not } \\
\text { capitalise on the movement economy } \\
\text { due to their distribution relating primarily } \\
\text { to the POS system. } \\
\text { Perception that street network is } \\
\text { predetermined by the alignment of the } \\
\text { POS system and as such is locked into } \\
\text { an inter-cardinal geometry which limits } \\
\text { solar-efficient layout }\end{array}$ & $\begin{array}{l}\text { Perception that the overarching POS } \\
\text { system severely limits the ability of } \\
\text { developers to adopt their own style and } \\
\text { for each precinct to have its own } \\
\text { distinctive 'sense of place.' }\end{array}$ & \\
\hline
\end{tabular}

Figure 7. This summary table sets out the Wungong LSP innovations and the reasons they have been resisted by the planning disciplines, developers and regulatory bodies.

\begin{tabular}{|c|c|c|}
\hline $\begin{array}{l}\text { Mitigating resistance from within planning and urban } \\
\text { design disciplines }\end{array}$ & Mitigating resistance from developers & Mitigating resistance from regulatory bodies \\
\hline $\begin{array}{l}\text { - Ensure design proposals have more peer review } \\
\text { through the process so you 'bring more people into the } \\
\text { tent as you go along...' }\end{array}$ & $\begin{array}{l}\text { - Include developers, and their development model, into } \\
\text { the early planning for innovative POS matrices. The } \\
\text { earlier the commercial reality is factored in the more } \\
\text { efficient the planning process will be.' }\end{array}$ & $\begin{array}{l}\text { Develop 'protected spaces' to allow experiments to } \\
\text { emerge and develop. For example drainage engineers } \\
\text { relaxing requirements around flow measurements, and } \\
\text { even-overzealous safety requirements in WSUD POS } \\
\text { models. }\end{array}$ \\
\hline $\begin{array}{l}\text { - Ensure peer review participants are 'independent and } \\
\text { impartial' and without ideological affinity with alternative } \\
\text { urban design/ planning models. }\end{array}$ & $\begin{array}{l}\text { - Reduce the number of developers to ease coordination } \\
\text { issues between development sites. For example use a } \\
\text { single land developer and bring them into the design } \\
\text { process early. }\end{array}$ & $\begin{array}{l}\text { - Create an overarching steering committee which } \\
\text { reflects the approval agencies required for particularly } \\
\text { integrated POS and stormwater matrices, so that } \\
\text { decisions can be made quickly and collaboratively and } \\
\text { ensure the group is maintained over the lifetime of the } \\
\text { project. }\end{array}$ \\
\hline $\begin{array}{l}\text { Provide a detailed account of what existing state } \\
\text { government policies planners are following and those } \\
\text { that they are deviating from - with an appropriate } \\
\text { justification. }\end{array}$ & $\begin{array}{l}\text { Develop a phasing strategy that allows the testing of } \\
\text { market demand, and actual usage of pilot POS projects } \\
\text { to reassure developers that innovative POS matrices } \\
\text { are usable, can increase land value, and subsequently } \\
\text { are worthy of investment. }\end{array}$ & \\
\hline $\begin{array}{l}\text { - Develop a scientific basis (such as a need-based } \\
\text { assessment) from which innovative POS systems can } \\
\text { be argued 'to work' so as to fend off related critiques } \\
\text { which are otherwise likely to surface. }\end{array}$ & $\begin{array}{l}\text { - Ensure planning for WSUD POS fully deals with the } \\
\text { science of hydrological issues so to not open such } \\
\text { planning to critique by those, from the development } \\
\text { community or elsewhere, who have differing agendas. }\end{array}$ & \\
\hline
\end{tabular}

Figure 8. This summary table sets out the mitigating strategies that planners could deploy in future urban projects attempting WSUD POS innovations.

within the planning disciplines. ${ }^{3}$ Indeed the 'adversarial' 2010 peer review of the Wungong LSP (Ellis 2010, 2 ), which occurred subsequent to change of state government, involved some planners who had previously been involved in authoring Perth's New Urbanism inspired Liveable Neighbourhoods' code. This was at a time when the suburban development industry was just adopting the Liveable Neighbourhoods and as such, its authors could have been sensitive to perceived challenges to this model, such as the Wungong LSP. In particular, the Liveable Neighbourhood's code aspires to emulate New Urbanism's avocation of compact, pedestrian-friendly neighbourhoods (Congress of
New Urbanism 2016) and the creation of smaller, more accessible neighbourhood parks (West Australian Planning Commission, \& Department of Planning 2015) (Figure 9).

Academic Richard Weller - who has published widely concerning Landscape Urbanism ${ }^{4}$ (Weller 2006a, 2006a, 2008, 2009) - initially led the planning of the project. Indeed, the LSP embodies the Landscape Urbanism notion that the landscape can function as a 'template for urbanism' (Weller 2006b, 67) - expressed in the Wungong LSP as a linear POS system which acts as the 'primary guidelines for urban development' (Weller 2008, 258). Some of the resistance emanating 


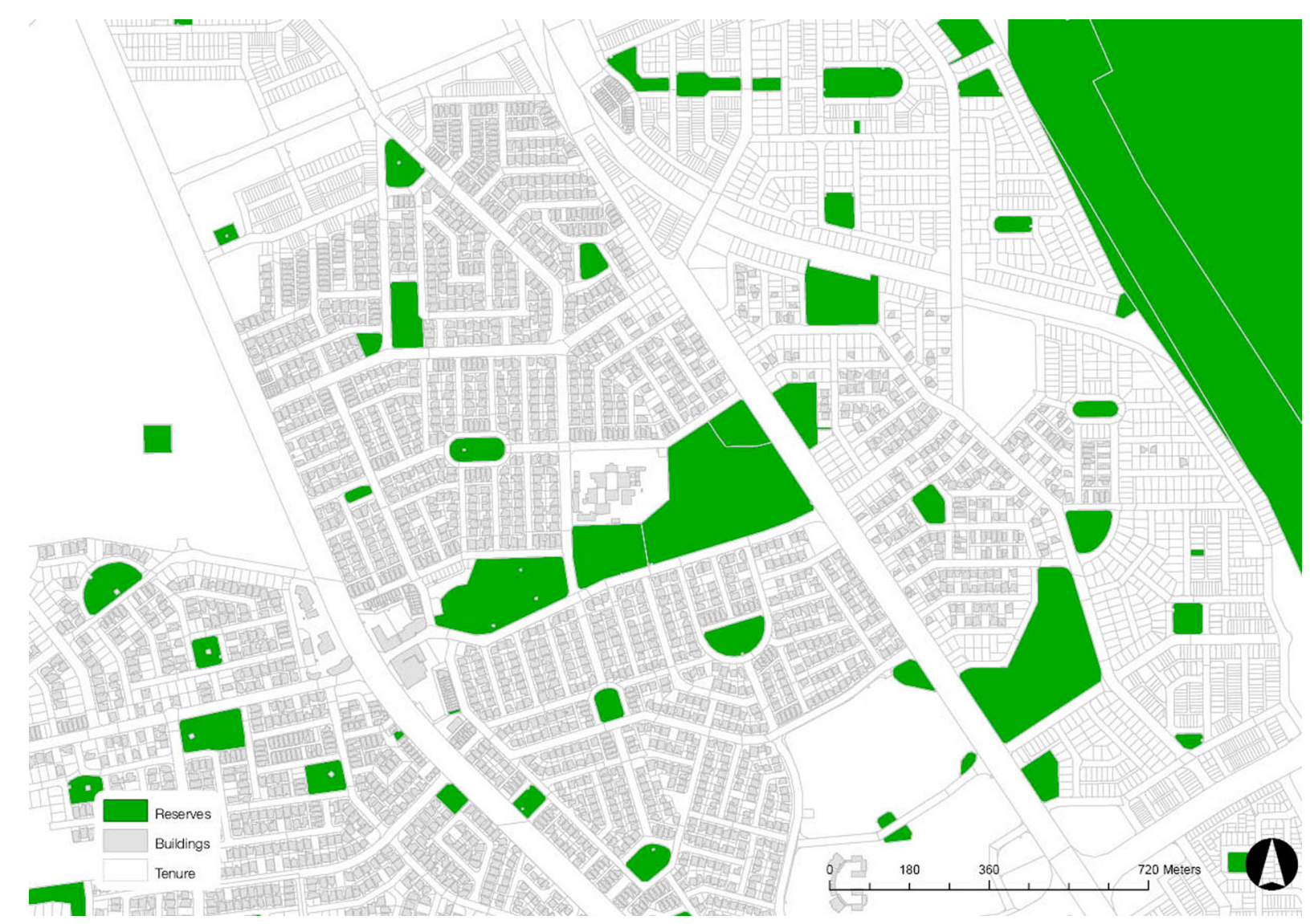

Figure 9. The Liveable Neighbourhoods/New Urbanism inspired suburb of Butler on Perth's northern development corridor has a typically disconnected POS system, the structure of which contrasts with the Wungong LSP's holistic and interconnecting POS system.

from within the Perth planning community we partly attribute to a general culture of antagonism between the New Urbanism and Landscape Urbanism camps, tensions that Andres Duany subsequently expressed in the book 'Landscape urbanism and its discontents' (Duany and Talen 2013a).

\section{Resistance to a holistic POS system}

The critiques of the Wungong LSP expressed in this review were numerous and tended to centre on the holistic, linear POS system. In particular the review regarded that the Wungong LSP proposed an 'inequitable' distribution of open space (Burrell $2010,1)$, inadequate provision of appropriately useable public open space, and an over-provision of narrow linear open spaces and consequent overreliance on schools providing shared sports fields (Jones et al. 2010, 3).

The critique of the Wungong LSP's linear POS system possibly stems from a long-standing ambivalence by New Urbanism to such models. Indeed the leader of the New Urbanist movement, Andrés Duany, has been particularly dismissive of linear parks, describing them as 'an extended venue for crime', and as a reoffering of the 'system of green as a buffer' which in his opinion will perpetuate the problematic dispersive tendencies of the modern city (In Kullmann 2011, 72). In this reading linear POS is regarded as 'forms of conveyance, zones of transitory content' and are not intentional, 'well articulated design projects' (Smith 1999, 77). Perhaps in the 2010 Wungong LSP peer review such sentiments tended to be expressed through a critique in which Wungong's linear POS system inadequately provided useable POS (Jones et al. 2010, 3,4).

\section{Resistance to an integrated POS and stormwater system}

While New Urbanism is generally ambivalent about the recreational useability of linear POS, the use of hydrology to inform the design of POS and related urban form also appeared to antagonise the review panel. The use of hydrological systems to inform POS and urban fabric is referred to in New Urbanist literature as comprising the 'hydrological privilege' (Duany and Talen 2013b, 7) in which hydrology is seen to be elevated above all other, more sensible, structuring devices for both POS and urban fabric - for example street networks, and urban form. Arguably, New Urbanism's broad lack of regard for hydrological function has found expression in the Wungong LSP review through criticisms questioning whether the Park Avenues and Living Streams actually constitute POS. Indeed the authors of the 
Wungong LSP peer review concluded that there was no need for hydrological and recreational functions to be so 'tightly bound' together (Jones et al. 2010, 7 ), and that planners should provide recreational amenity outside of the drainage network. ${ }^{5}$ This is in part because in periods of high rainfall, areas of the Living Streams become waterlogged, and as such, some view them as unusable (landscape architect). Some local government staff anecdotally shares the view, first expressed by the peer review panel, that the Living Streams and Park Avenues are not functional and leading to a deprivation of recreational opportunity - particularly from an active recreation perspective.

\section{Resistance to a POS system as the primary guidelines for development}

The 2010 reviewers of the Wungong master plan also heavily critiqued the POS network generated, urban form models which encapsulated the Landscape Urbanist notion of landscape operating as a 'structuring medium' (Duany and Talen 2013b, 4). As the review proclaims the scheme 'erroneously enforces a deeply flawed vision based on landscape elements' (Burrell $2010,1)$. Such critique resonates with the New Urbanist sentiment that Landscape Urbanism can make 'a bucolic contribution to civic space' but is 'ultimately incapable of delivering ordinary urban fabric' (Duany and Talen 2013b, 12). The review panel regarded the failures of the proposed urban fabric as numerous.

Firstly, it was expressed that the Wungong LSP lacked a mixed-use town centre with diversity of character both of which it was considered 'would normally underpin such a large structure planning area' (Burrell 2010, 5). Moreover it was regarded that the location and distribution of Activity Centres 'does not best capitalise on the movement economy or may have inadequate catchments to be feasible' (Jones et al. 2010 , 4) perhaps reflecting that the location of such centres was developed, in part, in relation to the POS system. Reviewers regarded there are also unrealistic expectations for developers to deliver substantial amounts of higher density housing around very small local neighbourhood centres (Jones et al. 2010, 4). Moreover, a lack of employment strategy was regarded as a project failing - as a reviewer concluded the master plan appears silent on matters of job creation (Burrell 2010, 1), again perhaps given its overt landscape focus. Finally, it was also considered that due to the privileging of hydrological systems the street network is 'largely predetermined by the alignment of the Park Avenues' (Sack et al. 2004, 26) and as such has been locked into an inter-cardinal geometry and as such limits potential for solar-efficient layout (Jones et al. 2010, 3). While there may be an element of truth in such criticisms, they also no doubt reflect, a deeper ambivalence that landscape in the form of a multifunctional POS system can structure urbanism that 'works' on a multitude of non-landscape levels.

\section{Resistance from land developers}

The land development community furthered resistance to the Wungong LSP. Subsequent to the 2008 change of state government, they identified several issues that they believed threatened the economic viability of development. ${ }^{6}$ Despite the ambitions of project planners to deliver a 'grand vision', developers believed that the holistic POS structure of the LSP posed various delivery problems through the detailed planning and construction phases. This was because these phases saw the Wungong project area divided into 13 cells, with each cell having a typically separate developer and requiring its own structure plan (Metropolitan Redevelopment Authority 2012a, 11) (Figure 10).

\section{Resistance to a holistic, integrated POS and stormwater system}

Partly because of this fragmented framework, the LSP's holistic POS and stormwater system poses issues in relation to the coordination of drainage networks from one cell to the next. As a project engineer explains:

In an area like this, which is essentially one big drainage catchment, the system breaks down when you cut it up into precincts - you cannot do an overarching design and retain it. As soon as someone starts saying 'we need a flat lot then you have changed the level of the roads, you've changed the drainage system and it all starts unravelling bit by bit ... . (civil engineer)

Moreover a project hydrologist on the Wungong project attests when 'a developer goes ahead here and sets a level for the drainage system, the people upstream cant connect their system in without having four metres of (sand) fill ... as such there is a perceived 'disconnect between what was the vision to actually what's the design' (hydrologist). In this respect, there is a perception amongst the developers that the LSP compounded such issues. As landscape architects who have been responsible for the detailed design of Living Streams in Wungong explain:

The Park Avenues and Living Streams did not really align with what was on the ground - the levels, the site geology, the hydrology, and what drains were there and where they were located... Formalising them into corridors reflected a lack of connection between the science and the design principles. (landscape architect)

According to this critique, while 'landscape issues', ostensibly drive the LSP it actually offers limited recognition of the topographical constraints of the redevelopment site. Indeed, the project reviewers assert that this 'limited recognition' in the project planning led 


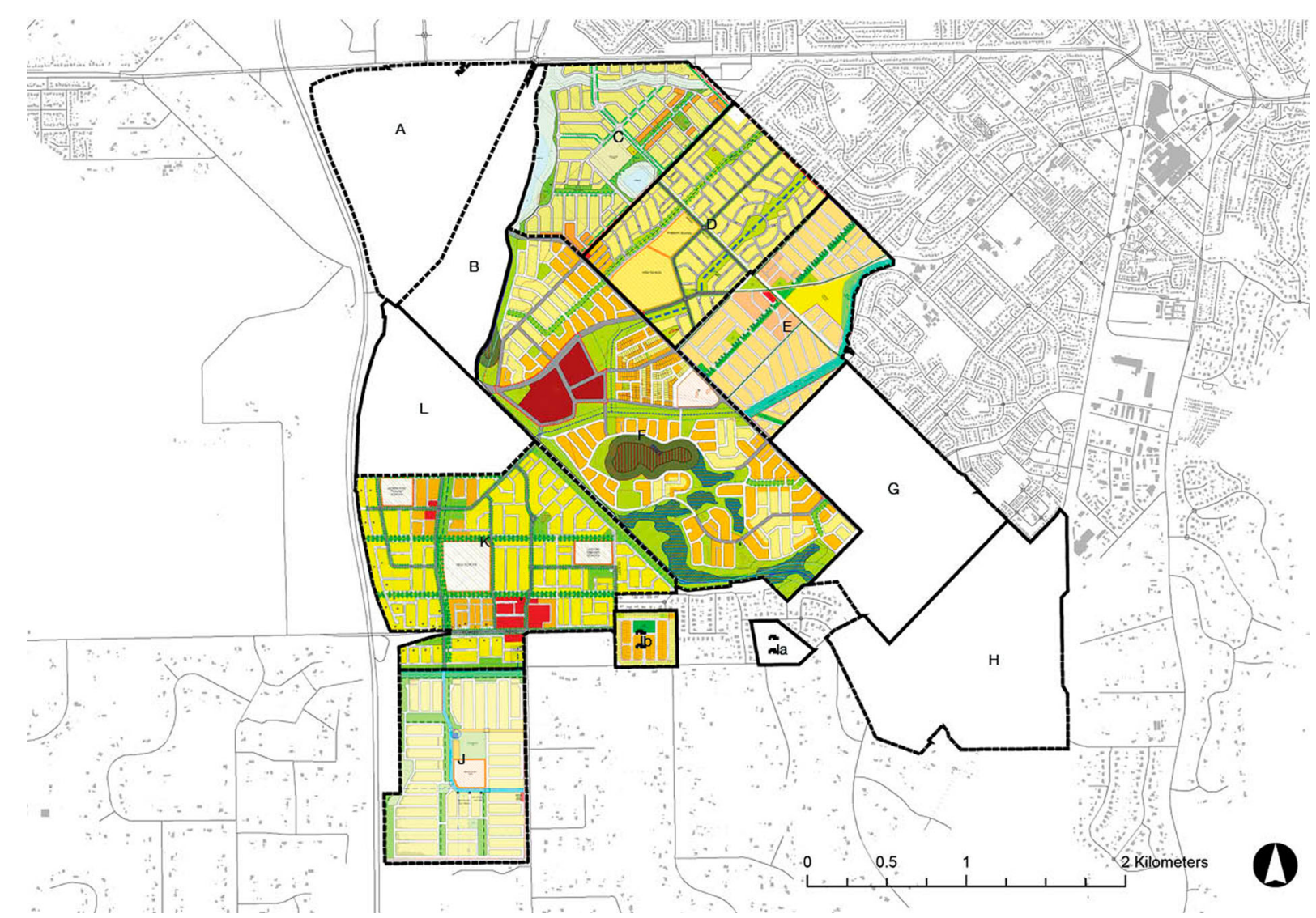

Figure 10. A comparative analysis of the structure plans for precincts $C, D, E, J$ and $K$ and the LSP reveals that the Park Avenue geometries have becomes much more convoluted and the street networks have deviate from the orthogonality of the LSP. Indeed the sense of 'Louis the Fourteenth coming to Perth ...' has been greatly diminished in the approved structure plans. Moreover the areas of 'urban density' proposed in the LSP appear to have been reduced, particularly in cell C and J.

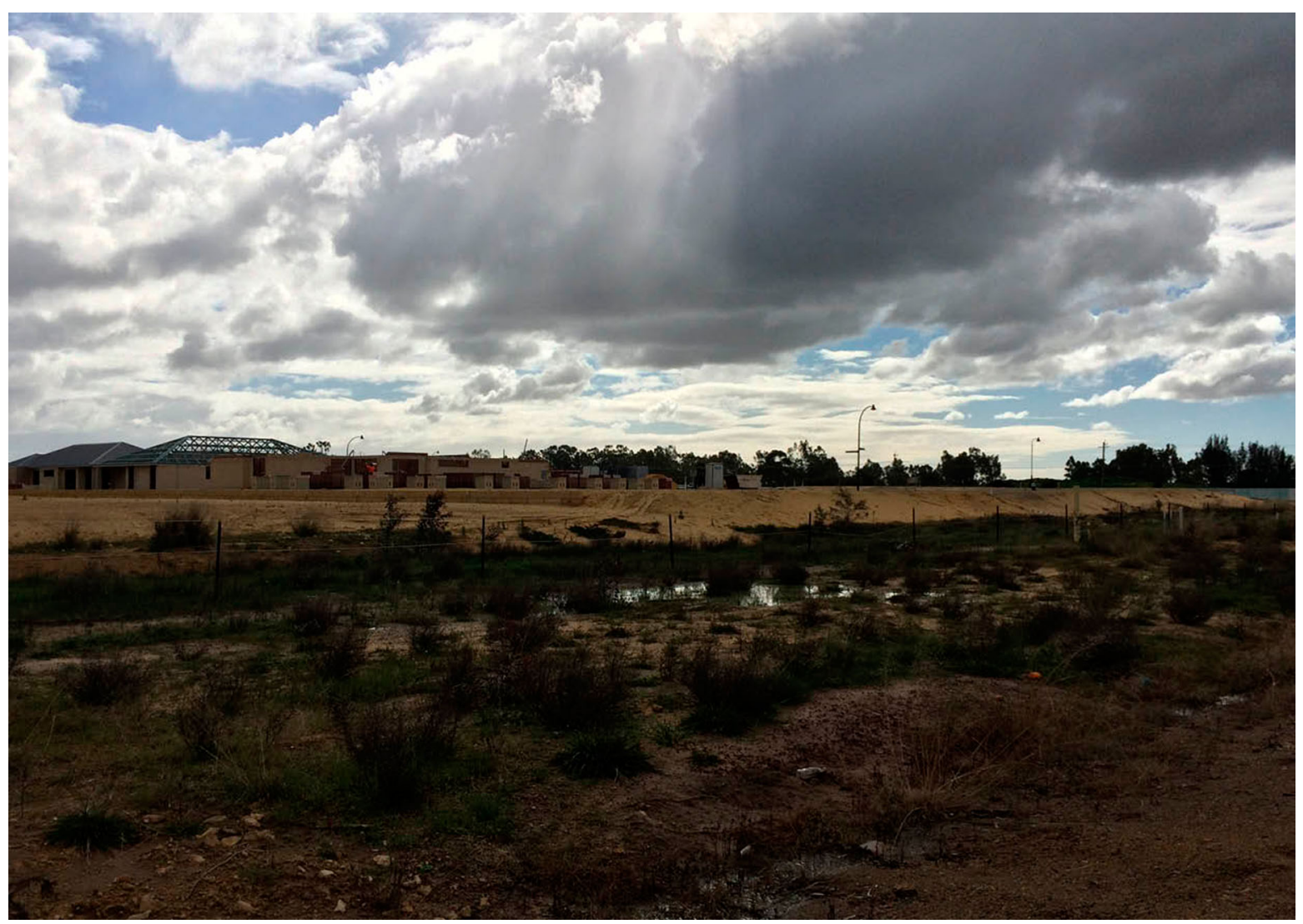

Figure 11. Like most suburban developments in Perth's geomorphic wetlands the Wungong project has required substantial amounts of fill. This has been exacerbated by the fill required to ensure the Living Streams flow in the correct directions. 


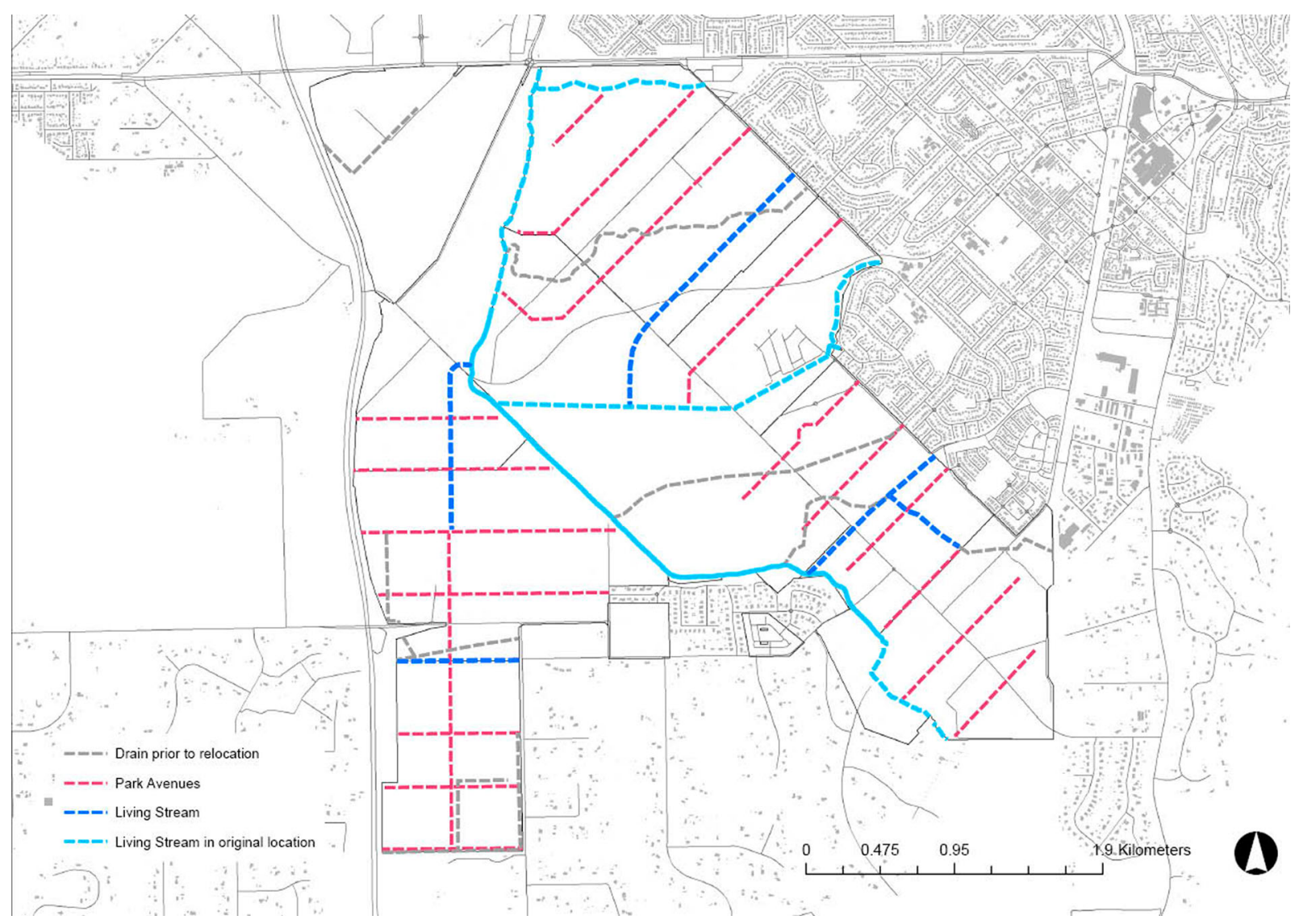

Figure 12. The 2010 Wungong LSP reviewers regarded that the Living Streams should have followed the alignment of the existing drains, as realignment of existing waterways they believed 'could severely compromise the integrity of the urban design to respond to its natural terrain' and in turn limit more cost effective solutions.

to the Living Streams and Park Avenues 'drainage ostensibly going up-hill in some cases', which in turn lead to 'unrealistic fill requirements' (Jones et al. 2010,2 ) (Figure 11). To ease such issues reviewers felt the Living Streams should have followed the alignment of the existing drains. Instead the reviewers felt that imposition of orthogonal Living Streams and Park Avenues 'severely compromised the integrity of the urban design to respond to its natural terrain' and be more cost-effective (Jones et al. 2010, 7) (Figure 12).

Compounding such issues, some of the developers also felt aggrieved by the Developer Contribution Scheme (DCS) set up to fund the implementation of a holistic, interconnected POS system - as opposed to a POS self-contained within particular development precincts. However, according to the 2010 peer review of the LSP, the planning team levied these costs 'on developers without an explanation of the percentage of use of others outside the redevelopment area or the extent to which users in one cell would take advantage of this infrastructure' (Jones et al. 2010, 10). As a result 'some of the developers at Wungong, who are down near the tip site (precinct J), feel like they have been lumped with this DCS and they get no value out of it ... They want to see that they are getting are return for their contributions' (landscape architect)
Because of such reasons, and also due to the fact that a DCS is not typically employed in a BAU suburban development in Perth, this has led to significant resistance from developers. As an interviewee explains 'while the rules written up to cover DCSs are clear, it doesn't get you past the politics. The developers drive hard bargains ...' (civil engineer).

\section{Resistance to a POS system as the primary guidelines for development}

While the development industry typically provided resistance to the Wungong LSP because of requirements for DCSs, coordination and the fill need to make the stormwater system function, the developers also believed the LSP overly limited their ability to adopt their own style for each precinct. ${ }^{7}$ As Richard Weller explains:

What irked the various developers and their design teams most, when they found they had to work with the overarching system of the avenues, was that they were not free to shape the plans of their subdivisions as they normally would. They argued, somewhat ironically, that the avenues limited their ability to create a distinctive 'sense of place' for their particular project .... $(2009,253)$

As an ex-project director explains this was particularly an issue with Stockland, one of the two major 
developers of the project: 'Stockland, like to put their own stamp on things ... they have a formula and having these kinds of Living Streams and Park Avenues did not work with their formula' (project director). The developers concerns about limitations on styling their developments were, no doubt, not alleviated by the LSP design team's assertion that 'the overall character and marketability of Wungong is that the project's identity is not to be achieved through cosmetic styling, but rather structural clarity' (Sack et al. 2004, 6) ....

\section{Resistance from regulatory bodies}

While the construction of the Wungong LSP is being overseen by the MRA, and is an official designated redevelopment area which is excised from the normal state and local government approval processes and policies (Ellis 2010,18) this has not always been enough to prevent resistance to the projects implementation at both a state and local government level.

\section{Resistance to an integrated POS and stormwater system}

One of the issues that a POS system with overlapping recreational and hydrological functions creates is a long list of regulatory bodies who are required to give approvals. Indeed, the MRA to the Department of Water (DoW), the Water Corporation, ${ }^{8}$ the City Of Armadale (who will eventually assume responsibility for the maintenance of the Wungong project), River and Estuaries, and the Department of Parks and Wildlife all oversee and approve design proposals for Wungong's Living Streams. The MRA are the managing agency, charged with the challenging exercise of securing these approvals. Nonetheless, this causes issues for the consultants. As landscape architects engaged in the Wungong project explain:

One of the real difficulties is that we are not encouraged to engage directly with the agencies. MRA are meant to coordinate and look through everyone's comments- if there are conflicting or irrelevant comments they are meant to filter them out ... (However) what that does is to remove your ability to talk directly with the agencies and work through comments.... (landscape architect)

The problem in this situation of overlapping interests is that, while the City of Armadale, the DoW, the MRA 'have all been pretty good and helpful but that's a real diversified of desired outcomes, ... we have had a real hard time resolving those conflicts' (hydrologist). This prolongs the period required for design and approvals significantly. This delay has further implications:

When (the approval process) is stretched out over two years the DoW change their policy on water treatment, MRA release an update to a POS policy, the local government change what vegetation types they are accepting, a policy comes out about bushfires, more information is released about cockatoo habitat trees and all these things change along the way. (landscape architect)

Compounding such issues, interviewees regarded the Water Corporation itself as an impediment to the delivery of multifunctional, integrated stormwater and POS matrices. ${ }^{9}$ As an ex-project director for the Wungong LSP describes 'Water Corporation's sole role - in relation to drains - is to move water ... "All we are required to do is this" is a standard response' when complex Living Stream models were tabled for approval (project director). Moreover, as an interviewee explains:

You have main drains controlled by the Water Corporation who have very specific rules about what you can put in them, what the levels must be, because all they care about is managing the main network from a hydraulic perspective to make sure nobody gets flooded. If you are trying to do clever things - such as Living Streams - you are going to have a challenge with the Water Corporation... (Indeed) the Water Corporation's initial starting point concerning the Living Streams was 'no we won't wear this at all'. (civil engineer)

Other issues pertained to how, until recently, Water Corporation measured peak flow rates at various intervals along a Living Stream network (landscape architect). The effect of this was designers were required to choke flows at various points along Living Stream corridors resulting in waterlogged areas that limit the useability of such areas from a recreation perspective - something that fuels controversy about whether Living Streams and Park Avenues constitute useable POS. As landscape architects on the project explain: 'either you want to have the usability or you choke the flows back - you can't have both' (landscape architect).

Compounding this complex approval process for achieving Living Streams is that while the MRA has control over the Wungong development process, the local government, the City of Armadale, will eventually assume responsibility for maintenance and as such have 'some' say on what is constructed (civil engineer). Nonetheless, the responsibilities for the ongoing maintenance of multifunctional stormwater and POS matrices are not clear. As one interviewee explains 'as soon as you have multiple organizational lines drawn over one bit of land we seem to have trouble dealing with it...' (civil engineer). This complexity arises from a situation in which Living Streams 'can't just be done in the drain corridor which is freehold land owned by Water Corporation, you need land either side so you need to reach a longer-term management, maintenance and liability agreement needs to be reached with the local authority. Who mows the lawn, who maintains the bike path needs to be worked out' (government representative) all of which adds to 
the complexity and time required for implementing Living Stream orientated POS.

\section{Mitigating resistance from the planning discipline}

The following section discusses how planners could seek to - mitigate the resistance from within the planning discipline, development community and regulatory bodies to POS innovations.

The critique of the Wungong LSP from both within the planning discipline and development community indicates that with substantial, complex POS driven projects design teams should 'have more peer review through the process so you bring more people into the tent as you go along...' (civil engineer). While the original Wungong LSP design team had a substantial 60 consultants representing 38 different organisations (Weller 2008, 257) there is also a need to incorporate also those who are likely to resist the project aims so that their concerns (where appropriate) are able to be constructively folded into the design process (Hoyer et al. 2011, 36). This reflects the maxim 'keep your friends close, but your enemies' closer ...'

At the same time, particular people, who possibly had an ideological reason for not supporting the project, carried out the 2010 Wungong peer review process. A situation that resulted in a review which employed 'adversarial language' and focused entirely on the negatives (Ellis 2010,2). The findings of such a review are thus inevitably 'diluted' and it can be difficult to ascertain what are 'real' planning issues that do require resolution - and those that have arisen for other reasons. Such a situation could fail to meet commonly held expectations about peer review being 'independent and impartial' (Design Council 2013, 2).

In saying this, the design teams should also provide a detailed account of what existing state government policies they are following, and those that they are deviating from, with an appropriate justification. For instance, urban designers from the LSP Wungong design team have indicated that the Wungong LSP is 'more Livable Neighbourhoods than most people think ...' (urban designer) and indeed 'residential areas are organised in accord with walkable distances to neighbourhood centres, streets form interconnected grids as opposed to cul-de-sacs, no buildings back onto POS, and generous streetscapes are prescribed' (Weller 2008, 263). Clarifying both the differences from, and similarities to, existing planning policies may help to neutralise unnecessary antagonism from those who might be wedded to current planning regimes.

Finally, the critique of the Wungong LSP from the perspectives of the inequitable distribution and provision of open space (Burrell 2010, 1; Jones et al. 2010, 3), remain conjecture. Ultimately such claims, need to be verified through a 'needs based assessment' of a similar demographic to those expected to live at Wungong. Such an assessment considers not only the total number of people within a given an area, but crucially also 'accounts for their socio-demographic composition, their leisure and recreation preferences and those of various sub-groups within this population, and the type and number of facilities required to serve those needs' (Sipe and Byrne 2010, 23). Without such detail being considered an assessment is likely to be a 'blind' application of generic POS standards (Sipe and Byrne 2010,21) or a 'rule of thumb' feeling - either of which is likely to be suspect. The lesson from this is that, having a scientific basis (such as a need-based assessment) from which innovative POS systems can be argued 'to work', is vital for fending off related critiques which are otherwise likely to surface.

\section{Mitigating resistance from developers}

The experience of delivering the early stages of the Wungong LSP certainly offers lessons for planners in terms of mitigating resistance from developers. Primarily it indicates the importance of having developers, and their development model, factored into the early planning for innovative POS matrices. For instance if the development model is to be precinct-based it is worth considering whether POS models should follow this lead and also be largely self-contained within precincts - something which would ease the resistance from developers who are required to fund the DCS for items they feel are disconnected from their development precinct. Alternatively, if POS matrices are holistic, and require substantial connectivity and coordination across multiple scales, then there exists potential in also reducing the number of developers. Indeed, planners bringing a single land developer into the design process earlier (civil engineer) could ease some of these coordination challenges. This said working with a single developer also entails particular risks as well, by risking everything on one endeavour. Planners should seek the input development early in the process because 'the earlier the commercial reality is factored in the more efficient the planning process will be' (project director).

Regardless of the development model pursued it is important that a phasing strategy is advanced that allows the testing of market demand, and actual usage of certain POS features, prior to rolling out innovate POS matrices across a broad scale. Such a pilot project could help to reassure developers that innovative POS matrices can increase land value, and subsequently are worth investing in. Such a process brings to mind Frederick Law Olmsted meticulously documenting the impact of Central Park on adjacent property values and demonstrating that the park made a 'profit' - data which was crucial in providing the justification for large urban parks in Manhattan but also a number of other North American cities (Crompton 2005, 218). 
The substantial critique, which the LSP has received from the development community regarding the amount of fill to make drainage work, highlights the need to have, more detailed, engineering advice on such proposals early in the process. As an interviewee explains 'perhaps we could have done a bit more engineering at the outset to test this philosophy about the drainage, in hindsight we have been a bit naïve in that respect - a bit more on the ground investigative work prior to moving two far forward' (project director). This point is of importance because as a project engineer explains 'if you want to do something as radical as this (LSP) you are going to hit uncertainties, it's easy for people to say, "This won't work ..." (civil engineer). By having a LSP that does not fully deal with the science of hydrological issues initially leaves such a document open to critique by those, from the development community or elsewhere, who have differing agendas.

\section{Mitigating resistance from regulatory bodies}

While the experience of delivering the Wungong LSP has implications for how policy makers should create a regulatory context that protects and facilitates innovation. The nurturing of innovation requires that we neutralise the overt risk averse culture embedded within and across organisations (in particular public agencies), 'where any failure, irrespective of context, is considered a negative outcome' (Farrelly and Brown 2011, 727). Because of this it is important that protected spaces are created to allow experiments to emerge and develop (Farrelly and Brown 2011, 729). In relation to the Wungong LSP this 'nurturing' environment would see drainage engineers, for instance have flexibility to relax requirements around flow measurements, and even around sometimes-overzealous safety requirements, which tend to compromise the useability of Living Stream environments, in particular.

Moreover, the project raises questions as to the governance arrangements for delivering such holistic, multifunctional POS driven projects. While the redevelopment authority model has worked well for delivering contentious projects elsewhere in Perth (Weller 2007), and elsewhere (Rigby and Breen 1996, 19), it appears to cause administrative issues when the governing authority is required to filter all information to, and from, the relevant government agencies. In this respect, innovative projects require an overarching steering committee, which reflects the approval agencies required for integrated POS and stormwater matrices, so that the committee can make decisions quickly, and collaboratively (Hoyer et al. 2011, 38). While the early LSP design team embodied this idea, it is important that planning ministers maintain this group over the lifetime of the project - as opposed to the breakdown of this model subsequent to the change of state government and respective planning ministers.
The relevant local government should ultimately be part of this working group, as they will likely be responsible for the long term, demanding maintenance regimes of such multifunctional POS matrices (Hoyer et al. 2011, 37). This is because such POS such situations often require a specialised appropriately skilled maintenance team separate to the parks and gardens maintenance teams typical of most councils (Hoyer et al. 2011, 78). Indeed if planners are to mitigate local government resistance to such POS system proposals, it will require that policy makers adequately fund the relevant local government to provide this level of maintenance to complex POS.

\section{Conclusion}

This paper has set out the innovative principles that characterise the Wungong LSP and considered the barriers to their implementation and what planners could do to mitigate such resistance in similar future projects. The Wungong LSP's overarching structure varies resonates with a long-established tradition of planners pushing open-space systems to the fore in suburban planning - such is in Riverside in Chicago and Castlecrag in Sydney (Weller 2009, 254). While these precedents are well established, as this paper is evidence the real challenge of innovative open space networks is not their planning, but how they are is reconciled with conditions 'on the ground' in all their economic, hydrological, ecological, social and political complexity. We have directed this paper towards this end.

\section{Notes}

1. Coordination of the delivery of the Wungong LSP shifted to the Metropolitan Redevelopment Authority in 2010 .

2. This statement is not meant to imply there was any wrong-doing occurring in this respect.

3. We use 'planners' as inclusive of urban design.

4. Landscape Urbanism is a landscape and urban design theory that emerged out of the nexus of Harvard University and the University of Pennsylvania in the early 2000's (Thompson 2011, 8). Landscape urbanism proposed that landscape systems should function as a 'template for urbanism' (Weller 2006b, 67).

5. In fact the land developers are only given $50 \%$ credit for Park Avenues and Living Streams as POS while conventional parks are credited as $100 \%$ POS (Metropolitan Redevelopment Authority 2012b, 12).

6. Representatives from the land development industry had been involved in the 2004-2007 planning for the LSP however had failed to raise substantive issues with the ability of the plan to be implemented (project director).

7. This was despite the fact that to enable a 'degree of flexibility, the LSP specified that an avenue could be adjusted to a distance of 30 metres ... but each development must ensure that the avenue enters and leaves any particular sub-division as demarcated on the master plan' (Weller 2008, 261). 
8. The Water Corporation's requirements hydraulic, safety, public liability related and in themselves can take some time to navigate and have approved (government representative).

9. The Department of Water and Water Corporation have recently been working collaboratively, though the Drainage for Liveability Program, to improve the ability of drains to deliver multiple drainage and recreation benefits - this program signifies an important change of thinking in the Water Corporation (government representative).

\section{Disclosure statement}

The Australian Urban Design Research Centre, where the author is employed, received funding from the Metropolitan Redevelopment Authority (MRA), for a related yet different project, at the time of writing this paper. The case study project 'Wungong' is an MRA project.

\section{Funding}

This work was supported by the Metropolitan Redevelopment Authority [grant number R15398].

\section{References}

Armadale Redevelopment Authority n.d. "Wungong Urban Developer Contribution Scheme (DCS) Presentation." Unpublished.

Australian Bureau of Statistics. 2017. "3222.0 - Population Projections, Australia, 2017 (Base) - 2066.” Australian Bureau of Statistics. Accessed August 23. https://www.abs. gov.au/AUSSTATS/abs@.nsf/Lookup/3222.0Main+Features 12017\%20(base)\%20-\%202066?OpenDocument.

Bolleter, J. 2016. "Background Noise: A Review of the Effects of Background Infill on Urban Liveability in Perth." Australian Planner 10: 1-14.

Burrell, Bill. 2010. Review of Urban Design and MasterPlanning Wungong Urban Water Master Plan. Perth: Taylor Burrell Barnett.

Carrington, Kerry, and Neil Marshall. 2008. "Building Multicultural Social Capital in Regional Australia." Rural Society 18 (2): 117-130.

Congress of New Urbanism. 2016. "The Charter of the New Urbanism." Congress of New Urbanism. Accessed August 15. https://www.cnu.org/who-we-are/charternew-urbanism.

Crompton, John. 2005. "The Impact of Parks on Property Values: Empirical Evidence from the Past Two Decades in the United States." Managing Leisure 10 (4): 203-218.

Design Council. 2013. Design Review: Principles and Practice. London: Design Council.

Duany, Andres, and Emily Talen. 2013a. Landscape Urbanism and Its Discontents: Dissimulating the Sustainable City. Gabriola Island: New Society Publishers.

Duany, Andres, and Emily Talen. 2013b. "Looking Backward: Notes on a Cultural Episode." In Landscape Urbanism and Its Discontents: Dissimulating the Sustainable City, edited by Andres Duany and Emily Talen, 1-16. Gabriola Island: New Society Publishers.

Ellis, John. 2010. "Management Response Review of Wungong Peer Review Report.” Unpublished.

Farrelly, Magan, and Rebekah Brown. 2011. "Rethinking Urban Water Management: Experimentation as a Way Forward?" Global Environmental Change 21 (2): 721-732.
Groat, Linda, and David Wang. 2002. Architectural Research Methods. Canada: John Wiley and Sons.

Hoyer, Jacqueline, Wolfgang Dickhaut, Lukas Kronawitter, and Björn Weber. 2011. Water Sensitive Urban Design: Principles and Inspiration for Sustainable Stormwater Management in the City of the Future. Hamburg: Jovis.

Jones, Evan, Bill Burrell, Wendy Morris, Tony Wong, and Les Stein. 2010. "Armadale Redevelopment Authority Wungong Urban Water Project Review." Wungong Independent Peer Review Panel.

Kelley, Kate, Belinda Clark, Vivienne Brown, and John Sitzia. 2003. "Good Practice in the Conduct and Reporting of Survey Research." International Journal for Quality in Health Care 15 (3): 261-266.

Kullmann, Karl. 2011. "Thin Parks/Thick Edges: Towards a Linear Park Typology for (Post) Infrastructural Sites." Journal of Landscape Architecture 6 (2): 70-81.

Metropolitan Redevelopment Authority. 2012a. Wungong Urban Development Contribution Scheme Report. Perth: Government of Western Australia.

Metropolitan Redevelopment Authority. 2012b. Wungong Urban Water Redevelopment Public Open Space Policy. Perth: Government of Western Australia.

Pen, Luke, and Karen Majer. 1994. "Drains Versus Living Streams." Paper presented at the How Do You Do It? Water Sensitive Urban Design Seminar 1994; Proceedings, Perth.

Rigby, Dick, and Ann Breen. 1996. The New Waterfront. London: Thames and Hudson.

Sack, Tinka, Andrew Nugent, Michael Rowlands, Margaret Grose, and Richard Weller. 2004. Brookdale - Planning from the Ground Up. Perth: The University of Western Australia.

Singh, B., Y. Pal, S. Clohessy, and S. Wong. 2012. Acid Sulfate Soil Survey in Perth Metropolitan Region, Swan Coastal Plain WA. Perth: Department of Environment and Conservation, Government of Western Australia.

Sipe, Neil, and Jason Byrne. 2010. Green and Open Space Planning for Urban Consolidation - A Review of the Literature and Best Practice. Brisbane: Griffith University.

Smith, Ken. 1999. "Linear Landscapes: Corridors, Conduits, Strips, Edges, and Segues." Harvard Design Magazine 77.

Thompson, Ian. 2011. "Ten Tenets and Six Questions for Landscape Urbanism." Landscape Research 37 (1): 7-26.

Weller, Richard. 2006a. "An Art of Instrumentality: Thinking Through Landscape Urbanism." In The Landscape Urbanism Reader, 69-86. New York City: Princeton Architectural Press.

Weller, Richard. 2006b. "Global Theory, Local Practice." Kerb 15: 66-71.

Weller, Richard. 2007. "Northbridge Link." Landscape Architecture Australia 114: 28-31.

Weller, Richard. 2008. "Landscape (Sub) Urbanism in Theory and Practice." Landscape Journal 27 (2): 247-267.

Weller, Richard. 2009. Boomtown 2050. Perth: University of Western Australia Press.

West Australian Planning Commission, \& Department of Planning. 2015. Liveable Neighbourhoods. https://www. dplh.wa.gov.au/getmedia/afb82ec4-31a5-4a14-8af4-c840b 3c2b81e/FUT-LiveableNeighbourhoods_2015.

Wong, Tony. 2006. "Water Sensitive Urban Design - the Journey Thus Far." Australian Journal of Water Resources 10 (3): 213-220.

Wood-Gush, Brett. 2008. "Wungong Urban Water Project: Going Beyond Liveable Neighbourhoods in the Pursuit of Environmental Planning Best Practice." Australian Planner 45 (2): 8-11. 